Kumawula, Vol. 4, No.1, April 2021, Hal 8 - 14

DOI: https://doi.org/10.24198/kumawula.v4i1.29574

ISSN 2620-844X (online)

Tersedia online di http://jurnal.unpad.ac.id/kumawula/index

\title{
PEMBERDAYAAN MASYARAKAT MELALUI PELATIHAN KEWIRAUSAHAAN DAN PEMASARAN DIGITAL PADA BUMDES BLULUKAN GEMILANG
}

\author{
Putri Nugrahaningsih1, Sri Hanggana ${ }^{2}$, Sri Murni ${ }^{3}$, Santoso Tri Hananto ${ }^{4}$, \\ Andi Asrihapsari ${ }^{5}$, M. Syafiqurrahman ${ }^{6}$, Renata Zoraifi ${ }^{7}$, dan Sri Hantoro ${ }^{8}$ \\ 1,2,3,4,5,6,7,8 Sekolah Vokasi, Universitas Sebelas Maret
}

*Korespondensi : putrinugrahaningsih@staff.uns.ac.id

\begin{abstract}
BUMDes (Village Owned Enterprise) Blulukan Gemilang is a business unit and an economic resource for the village, the goal of establishing a BUMDes is to reduce poverty based on an entrepreneurship spirit through a business unit and a waste management unit. The objectives of this community service activity are (1) to increase entrepreneurial spirit; (2) to provide insight about digital marketing. Therefore, it is necessary to develop competence and entrepreneurship as an advanced phase from the initial phase of establishing BUMDes. The community service method that was used is the participatory method, which is a method that is oriented towards efforts to increase the direct participation of the community in various processes and implementation, by means of assistance by conducting training on entrepreneurship and marketing mechanisms and providing assistance in marketing by promoting products from confection units such as apparel, mask products that have been produced to the local market. The result shows that the implementation of community empowerment which is carried out has experienced several obstacles in terms of production, due to limitations of the production machine capital and product marketing channels that have not used digital media. Therefore, the service team provided fixed asset capital assistance in the form of a cloth cutting machine to increase mask production. In the next step, the community service team provides assistance in the form of literacy activities about digital information through digital marketing training with social media and mask product design during the pandemic as a step to foster an entrepreneurial spirit. After training, participants are expected to be ready to take action to apply the entrepreneurial spirit. The results of the community service activities carried out at BUMDes Blulukan Gemilang have resulted that the village has been able to get revenue generated by synergizing with community empowerment.
\end{abstract}

Keywords: community empowerment; entrepreneurship;digital marketing, BUMDes

\begin{abstract}
ABSTRAK
BUMDes Blulukan Gemilang merupakan unit usaha dan sumber ekonomi bagi desa, tujuan pendirian BUMDes untuk mengurangi angka kemiskinan dengan berlandaskan jiwa kewirausahaan melalui unit usaha konfeksi dan unit pengelolaan sampah. Tujuan dari kegiatan pengabdian masyarakat ini adalah (1) meningkatkan jiwa kewirausahaan; (2) memberikan wawasan tentang pemasaran digital. Oleh karena itu, perlu pengembangan kompetensi dan kewirausahaan sebagai fase lanjutan dari fase awal pendirian BUMDes. Metode pengabdian masyarakat yang digunakan adalah partisipatif, yaitu metode yang berorientasi kepada upaya peningkatan peran serta masyarakat secara langsung dalam berbagai proses dan pelaksanaan, dengan cara pendampingan dengan cara mengadakan pelatihan tentang kewirausahaan dan mekanisme pemasaran serta memberikan pendampingan dalam pemasaran dengan mempromosikan produk hasil unit konfeksi seperti pakaian jadi, produk masker yang telah dihasilkan ke pasar lokal. Hasil pengabdian menunjukkan bahwa pelaksanaan pemberdayaan masyarakat yang dilaksanakan mengalami beberapa kendala dalam hal produksi dikarenakan adanya keterbatasan modal mesin produksi dan saluran pemasaran produk yang belum menggunakan media digital. Oleh karena itu, tim pengabdi memberikan bantuan modal aset tetap berupa mesin potong kain untuk memperbanyak produksi masker. Langkah selanjutnya, tim pengabdi melakukan pendampingan berupa kegiatan literasi tentang informasi digital melalui pelatihan pemasaran digital dengan media sosial dan desain produk masker di masa pandemi sebagai langkah memupuk jiwa kewirausahaan. Setelah pelatihan, peserta diharapkan siap beraksi menerapkan jiwa wirausaha.
\end{abstract}


Hasil kegiatan pengabdian masyarakat pada BUMDes Blulukan Gemilang telah menunjukkan bahwa desa telah mampu mendapatkan revenue generating dengan bersinergi dalam pemberdayaan masyarakat.

Kata Kunci: pemberdayaan masyarakat; kewirausahaan; pemasaran digital, BUMDes

\section{PENDAHULUAN}

Seperti amanah dalam peraturan perundangan yang dikutip dalam UU Desa Nomor 6 Tahun 2014 tentang desa terdapat pada pasal 87 ayat 1 dijelaskan bahwa dalam rangka meningkatkan pendapatan asli desa (PADes), desa berinisiatif dan berkewajiban untuk mendirikan Badan Usaha Milik Desa (BUMDes) sebagai salah satu langkah untuk program permberdayaan masyarakat yang mana BUMDes merupakan bagian dari penyelenggaran pemerintahan desa sekaligus mampu memenuhi kebutuhan masyarakat. Peraturan lainnya terkait hal yang sama yaitu diterbitkannya Peraturan Menteri Nomor 4 Tahun 2015 tentang BUMDes oleh Kementerian Desa, Transmigrasi dan Daerah Tertinggal. Selanjutnya, pemerintah desa akan menerbitkan dan menyusun Perda tentang Tata Cara Pembentukan dan Pengelolaan Badan Usaha Milik Desa. Kedua persyaratan ini telah ada dan dilaksanakan dengan baik oleh BUMDes mitra desa yang dijadikan obyek pengabdian masyarakat oleh tim pengabdi UNS. BUMDes telah beroperasi berdasarkan Perdes Nomor 4 Tahun 2017 yang berlokasi di Perum Flamboyan, Colomadu, Karanganyar. BUMdes diharapkan mampu meningkatkan pendapatan masyarakat dan desa, Pemerintah Desa Blulukan mendirikan Badan Usaha Milik Desa sesuai dengan kebutuhan dan potensi desa. BUMDes Blulukan Gemilang telah berbadan hukum dengan nomor register 3313121006 . Permasalahan yang acapkali terjadi disebabkan karena pengetahuan dalam perencanaan dan pengelolaan serta sumber daya manusia yang kurang kompeten. Alasan utama pemilihan objek penelitian di BUMDes Blulukan Gemilang, Colomadu, Karanganyar adalah karena BUMDes merupakan unit ekonomi yang sedang berkembang, serta memiliki pengelola yang berjiwa kewirausahaan hal ini didukung dengan adanya produk hasil olahan sampah organik dan mampu menggerakkan kegiatan womenpreneurship. Pemberdayaan masyarakat adalah langkah-langkah menguatkan sisi kelembagaan masyarakat terutama perangkat desa dengan tujuan supaya mampu meningkatkan kemandirian serta kesejahteraan masyarakat sehingga nantinya diharapkan mampu mewujudkan keadilan sosial yang merata serta berkelanjutan (Sumaryadi, 2005). Menurut Rahmawati, dkk (2017) tujuan pemberdayaan mengacu pada tingkatan atau pencapaian hasil perubahan sosial, memberdayakan masyarakat miskin, tidak memiliki kekuasaan, minimnya pengetahuan serta ketidakmampuan memenuhi kebutuhan infrastruktur, sosial, dan ekonomi.

Masyarakat desa sepenuhnya dalam melaksanan pengelolaan BUMDes dengan asas dari desa, untuk desa, dan oleh desa. Mekanisme kerja dilaksanakan dengan mewadahi kegiatan-kegiatan ekonomi masyarakat dalam kelembagaan secara profesional yang berlandaskan pada potensi sumber asli dari desa. BUMDes diharapkan mampu menjadi akar kemandirian yang berlandaskan pada kegiatan ekonomi masyarakat yang produktif dan efektif serta dikembangkan sesuai dengan ciri khas desa sehingga nantinya menjadi revenue generating bagi desa.

Dalam Hasnawati (2018), ekonomi kerakyatan yang didukung dengan kekuatan ekonomi rakyat yang memberikan kesempatan luas kepada masyarakat untuk berpartisipasi yang mana hasilnya dapat dinikmati oleh seluruh lapisan masyarakat, dalam tujuan jangka panjang perekonomian menjadi berkembang baik.

BUMDes di Desa Blulukan resmi terbentuk pada tanggal 8 September 2017 berdasarkan Perdes Nomor 04 Tahun 2017 yang diinisiasi oleh Kades, BPD dan juga masyarakat Desa Blulukan bekerja sama dengan Pemerintah Desa Blulukan kemudian diberi 
nama "BUMDes Blulukan Gemilang" yang telah disahkan oleh Bapak Kepala Desa, Slamet Wiyono dan ditetapkan melalui Peraturan Desa (Perdes). Hasil wawancara dan juga pengamatan langsung di lapangan tentang program usaha yang dikelola BUMDes Blulukan Gemilang yang mana telah menjalankan beberapa unit untuk kebutuhan masyarakat. Pengelolaan BUMDes yang sebelumnya dikelola oleh desa, sekarang menjadi tanggung jawab pengelola BUMDes untuk mengelola dan menjalankan. Program pertama, terkait unit konfeksi yang dijalankan dengan melibatkan partisipasi aktif ibu rumah tangga yang tidak berprofesi tetap sehingga mampu meningkatkan perekonomian serta pemberdayaan masyarakat sekitar.

Program yang kedua, yaitu unit pengambilan dan pengolahan sampah. Dengan adanya BUMDes di Desa Blulukan sehingga program dapat terkelola dengan baik, awalnya dikelola oleh paguyuban perorangan dengan pembayaran dibayarkan langsung kepada pengambil sampah tersebut. Setelah, adanya keberadaan program BUMDes, sistem pengambilan sampah berjalan rutin dan pembayaran dibayarkan kepada petugas BUMDes.

Seperti kondisi eksisting saat ini, kontribusi BUMDes dalam menguatkan ekonomi desa belum sepenuhnya memenuhi dan meningkatkan pendapatan desa dikarenakan desa belum cukup keterampilan untuk sumber daya manusianya (Ramadana, Heru, dan Suwondo, 2013).

Salah satu langkah konkrit dalam penguatan manajemen BUMDes, tim pengabdi melaksanakan pelatihan digital marketing dan desain produk. Adanya pergeseran pola di mana konsumen beralih menggunakan platform digital, menjadikan digital marketing sebagai peluang yang harus dimanfaatkan (Susanti, Gunawan, \& Sukaesih, 2019). Digital Marketing untuk BUMDes ini hakikatnya berbeda dengan metode pemasaran umumnya, dalam pemasaran berbasis digital, seorang penjual dapat berkomunikasi secara daring (online) dengan calon pembeli, sehingga saluran distribusi pemasaran dapat diakses dengan cepat dan mampu menjaring konsumen lebih banyak untuk dapat mengakses dan mendapatkan informasi dari produk atau jasa yang ditawarkan BUMDes. Sebagai langkah pemasaran produk secara cepat, media sosial sebagai media digital marketing BUMDes dapat memberikan informasi produk atau jasa yang dimiliki BUMDes dengan beragam akses, seperti website, blog, media sosial (Instagram, Facebook, Whatsapp), yang mana banyak calon pembeli yang berminat terhadap produk BUMDes (Ariyanto, 2020).

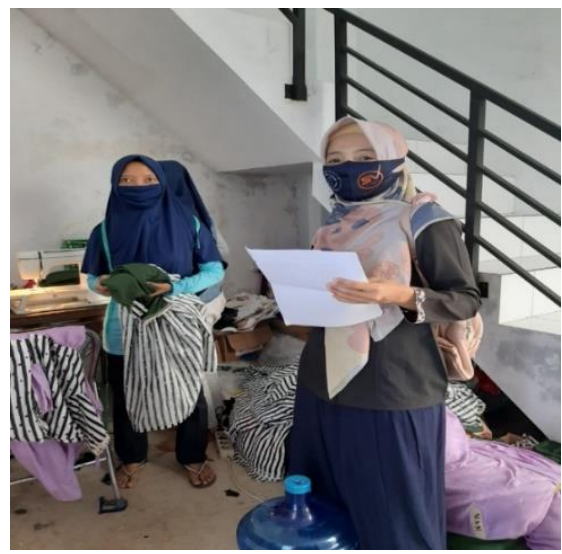

\section{Gambar 1. Survei pendahuluan dan tinjauan lokasi BUMDes}

Dari hasil survei dan tinjauan lokasi ke BUMDes terdapat dua permasalahan yang dapat diidentifikasikan sebagai dasar di dalam pelaksanaan kegiatan pengabdian. Pertama adalah 1) bagaimana cara menumbuhkan dan menggali jiwa kewirausahaan bagi pengelola BUMDes dan masyarakat di Blulukan dan 2) bagaimana cara meningkatkan pengetahuan pemasaran digital bagi unit konfeksi BUMDes. Dari kedua permasalahan yang ada tersebut, maka tujuan dari pelaksanaaan kegiatan pengabdian kepada masyarakat di Desa Blulukan, Kecamatan Colomadu, Karanganyar adalah 1) menumbuhkan dan menggali jiwa kewirausahaan dan 2) Meningkatkan pengetahuan pemasaran digital pada unit konfeksi BUMDes.

\section{METODE}

Metode yang diterapkan dalam pengabdian masyarakat ini adalah partisipatif. Pendekatan yang berfokus dalam sarana 
peningkatan peran serta masyarakat secara aktif dalam berbagai proses. Participatory Rapid Appraisal (PRA) atau penilaian desa secara partisipatif adalah metode yang tepat diterapkan agar masyarakat mampu mengevaluasi dan menganalisa hidup agar berhasil menyusun rencana dan kegiatan dalam konteks pengetahuan (Chambers dalam Sururi, 2020). Teknik pengumpulan data dilakukan dengan wawancara, dokumentasi, dan observasi.

Metode yang diterapkan dalam pengabdian masyarakat adalah dengan penyuluhan dan pendampingan dengan cara:

1. Memberikan penyuluhan kepada pengelola BUMDes dan masyarakat (ibu-ibu rumah tangga) tentang kewirausahaan dan sarana pemasaran digital.

2. Memberikan pendampingan dalam pemasaran dan mempromosikan produk hasil unit konfeksi

Prosedur kerja yang mencakup kegiatan dan indikator pengukuran keberhasilan dapat dilihat pada tabel 1 berikut.

Tabel 1

Prosedur Kerja

\begin{tabular}{cll}
\hline Tahap & \multicolumn{1}{c}{ Kegiatan } & \multicolumn{1}{c}{ Indikator } \\
\hline $\mathbf{1}$ & Penyuluhan, & Pemahaman \\
& pelatihan, diskusi & jiwa \\
& kewirausahaan, dan & kewirausahaan \\
& manajemen & dan media \\
& pemasaran & pemasaran \\
& & melalui diskusi \\
& & tanya jawab \\
\hline 2 & Pendampingan & Meningkatkan \\
& marketing skill dan & jumlah \\
& mempromosikan & penjualan dan \\
& produk Unit & pendapatan \\
& Konfeksi BUMDes & \\
\hline
\end{tabular}

Kegiatan pengabdian dilaksanakan dengan tahapan berikut ini:

1. Tahapan pendahuluan, rencana pengabdian mitra desa (BUMDes) memberikan persetujuan kerjasama untuk mengadakan serangkaian aktivitas pengabdian dengan perjanjian mitra dibuktikan dengan persetujuan pasa surat mitra kerjasama program pelatihan pemasaran digital dan kewirausahaan.

2. Tahapan pelaksanaan, mitra desa menyediakan fasilitas sarana pelatihan dan waktu untuk melakukan observasi dan wawancara

Tim pengabdian melaksanakan pendampingan dalam bentuk penyuluhan dan pelatihan kewirausahaan serta evaluasi yang mana tim menyiapkan bahan materi serta contoh desain masker (produk) untuk dipasarkan supaya menunjang kegiatan yang akan dilakukan.

\section{HASIL DAN PEMBAHASAN}

Pada tahap pendahuluan, tim sudah melakukan wawancara pendahuluan dan observasi terkait rencana pengabdian masyarakat dengan BUMDes Blulukan Gemilang serta mendapat ijin dari kepala Desa. Hal ini didukung pula dengan permintaan dari warga untuk memperdalam pengetahuan mereka mengenai kewirausahaan dan strategi pemasaran. Pelatihan ini memberikan pengetahuan keterampilan dalam memasarkan serta cara menciptakan produk konfeksi utamanya masker yang berkualitas. Hal ini dikarenakan kondisi pandemi Covid-19, kegiatan mempromosikan produk dengan menggunakan beberapa variabel promosi, dan juga memberikan penyuluhan bagaimana produk-produk yang sudah dibuat dapat dipasarkan dengan baik hingga sampai ke pelanggan. BUMDes Blulukan Gemilang menjalankan kegiatan usaha konfeksi yang menerima order berbagai macam produk baik partai kecil maupun partai besar. Selama ini telah membuat aneka produk fashion dan pesanan seperti baju, celana, daster, sprei, dompet, tas hingga produk yang menjadi komuditas saat ini yaitu masker. Sistem produksi yang dijalankan berdasarkan pesanan (job order). Lingkup pemasaran unit konfeksi meliputi area Solo dan sekitarnya serta melayani pesanan di luar area Solo. Pada unit usaha konfeksi ini memiliki 6 karyawan yang berasal dari lingkup masayarakat desa. Pelatihan digital marketing dan desain produk diselenggarakan di Sumringah Resto, Colomadu pada 21 Agustus 2020, dengan 
jumlah 20 peserta bertujuan untuk meningkatkan pengetahuan kewirausahaan kepada pengurus dan karyawan BUMDes Blulukan Gemilang terutama unit konfeksi, BUMDes Blulukan Gemilang, Colomadu, Karanganyar sehingga mereka memiliki bekal kemampuan untuk menangkap peluang ditengah pandemi Covid-19 yaitu dengan menciptakan desain produk masker yang marketable dan mampu memasarkan dengan media digital marketing, sehingga dapat meningkatkan taraf hidup masyarakat dan mampu menghasilkan revenue generating bagi kinerja BUMDes. Dalam pelatihan tersebut peserta dipandu oleh narasumber yang merupakan seorang pengusaha yang memiliki pengalaman media digital marketing dan melakukan studi pasar untuk desain masker (solosae.com, 2020).

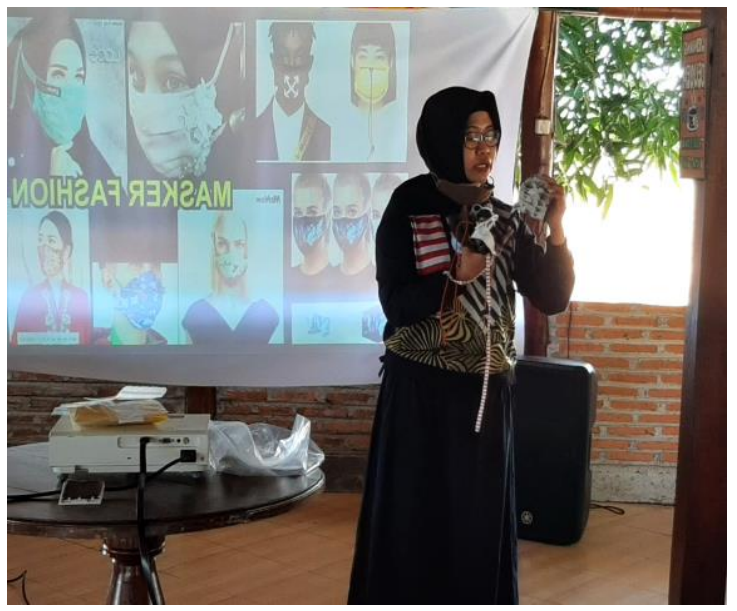

\section{Gambar 2. Pemaparan materi pelatihan desain masker dan digital marketing}

Teknologi yang telah hadir memberikan beragam manfaat dan kemudahan bagi setiap individu dan dalam banyak aspek, terutama dengan hadirnya internet (international networking). Adanya internet setiap individu dapat dengan mudah berkomunikasi baik lokal bahkan internasional, dapat dilakukan real time kapanpun dan di manapun, bisa melalui media sosial saja. Di samping itu, dengan internet kegiatan dan transaksi tidak harus dilakukan secara offline mendatangi toko, kantor atau gerai sehingga mudah dan tidak mengganggu aktivitas yang dimiliki (Nugrahaningsih, 2020).

Kegiatan pelatihan pemasaran digital dipandu narasumber berpengalaman dalam dunia kewirausahaan, peserta diajak mengenal strategi pemasaran digital melalui berbagai media terdiri dari website yang berisi profil BUMDes, produk hasil unit konfeksi dengan menyampaikan keunggulan produk; media sosial seperti Facebook, Instagram dengan menggunakan akun profil bisnis, serta Whatsapp juga bisa digunakan untuk media pemasaran; selanjutnya tim akan memandu pengelola BUMDes untuk dapat mengapliaksikan teori tersebut ke dalam unit bisnisnya sehingga tercapai target sasaran dan jangkauan pemasaranpun menajdi lebih luas. Pengelola BUMDes dibantu admin kemudian mencoba membuat akun instagram sebagai profil bisnisnya, kemudian menginklankan atau dengan menyewa endorse supaya produknya cepat dikenal khalayak masyarakat.

Untuk desain produk masker sebagai hasil produk konfeksi, tim memberikan masukan masker yang berkualitas SNI (Adhiyasasti, 2020) dengan desain sebagai berikut.

1. Tepi wajah harus tertutup masker dengan baik.

Masker harus berukuran cukup lebar menutup sebagian besar pipi dan hidung. Desain masker ini bisa mencontoh desain masker bedah sekali pakai atau bisa seperti model duckbill.

2. Adanya tali pengikat atau karet pengait masker.

Tali masker harus mampu menahan masker pada posisi yang benar dan tidak mudah bergeser sehingga membuat si pemakai sering memegang wajah.

3. Masker berlapiskan beberapa lapis kain.

Masker sesuai standar, diharuskan terdiri dari beberapa lapis kain. Kain terbuat dari bahan yang tidak melar.

4. Masker tidak menghalangi pernapasan Masker didesain nyaman dan tidak terlalu tebal sehingga tidak menghalangi pernapasan tapi tetep menutupi hidung dan mulut.

5. Bentuk tetap walau sudah dicuci berkali-kali

Kain masker harus berbahan bagus dan tidak berubah bentuk ketika dicuci 
seperti melar atau mengkerut jika dicuci dengan mesin pencuci.

Untuk mendukung proses produksi, tim pengabdian juga memfasilitasi BUMDes bantuan modal berupa alat produksi untuk meningkatkan kinerja unit konfeksi dengan memberikan mesin potong kain (cutting machine) sehingga bisa mempercepat proses produksi. Hal ini diharapkan target produksi BUMDes akan tercapai dan mampu memenuhi target pasar.

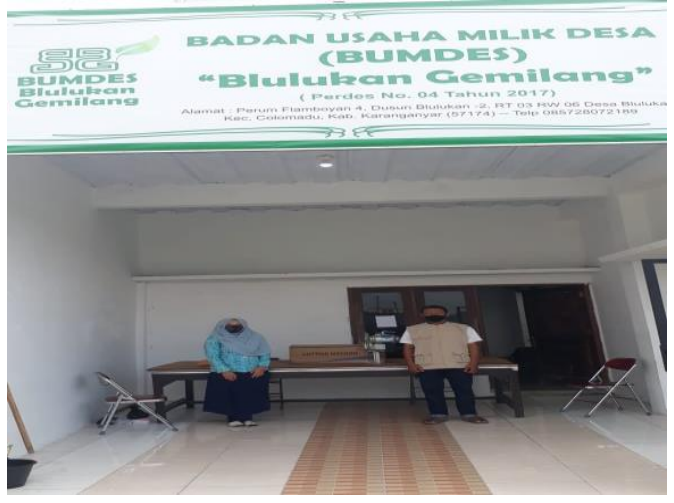

\section{Gambar 3. Kegiatan serah terima alat bantuan modal cutting machine}

Di akhir penyuluhan, tim memberikan kesempatan kepada peserta untuk mengajukan pertanyaan baik saran dan masukan sebagai ukuran evaluasi terhadap pemahaman dan antusiasme dari peserta terhadap kegiatan Abdimas ini. Tujuan kegiatan diharapkan mampu menumbuhkan jiwa kewirausahaan dan meningkatkan perekonomian desa yang disajikan pada tabel 2 berikut ini.

\section{Tabel 2}

Tingkatan Ketercapaian Pemahaman Peserta terhadap Pelatihan Kewirausahaan dan Manajemen Pemasaran

\begin{tabular}{|c|c|c|c|}
\hline $\begin{array}{c}\text { Kegia } \\
\text { tan }\end{array}$ & Materi & Indikator & $\begin{array}{c}\text { Ketercapa } \\
\text { ian }\end{array}$ \\
\hline $\begin{array}{l}\text { Tahap } \\
\text { Penyul } \\
\text { uhan }\end{array}$ & $\begin{array}{l}\text { Sosialisasi } \\
\text { dan diskusi } \\
\text { kewirausaha } \\
\text { an dan } \\
\text { strategi } \\
\text { pemasaran }\end{array}$ & $\begin{array}{l}\text { Menilai } \\
\text { pemahaman } \\
\text { tentang } \\
\text { kewirausahaa } \\
\mathrm{n} \text { dan } \\
\text { pemasaran } \\
\text { langsung } \\
\text { melalui tanya } \\
\text { jawab }\end{array}$ & $\begin{array}{l}\text { Peserta } \\
\text { memahami } \\
\text { materi } \\
\text { penyuluhan } \\
\text { mengenai } \\
\text { kewirausah } \\
\text { aan dan } \\
\text { strategi } \\
\text { pemasaran }\end{array}$ \\
\hline $\begin{array}{l}\text { Tahap } \\
\text { pendam } \\
\text { pingan }\end{array}$ & $\begin{array}{l}\text { Pendampin } \\
\text { gan cara } \\
\text { memprom } \\
\text { osikan }\end{array}$ & $\begin{array}{l}\text { Mampu } \\
\text { melakukan } \\
\text { kegiatan }\end{array}$ & $\begin{array}{l}\text { Mampu } \\
\text { meningkat } \\
\text { kan } \\
\text { penjualan }\end{array}$ \\
\hline
\end{tabular}

$\begin{array}{lll}\text { melalui } & \text { strategi } & \text { dan } \\ \text { pemasaran } & \text { pemasaran } & \text { keuntungan } \\ \text { langsung } & & \\ \text { dan iklan } & & \\ \text { serta } & \\ \text { mendistrib } & \\ \text { usikan } & \\ \text { produk } & \\ \text { yang } & \\ \text { dihasilkan } & \\ \text { ke } & \\ \text { pelanggan } & \end{array}$

Di akhir penyuluhan, peserta diminta untuk memberikan komitmen dan tim akan mengadakan monitoring dan evaluasi terkait kegiatan pengabdian. Peserta berasal dari unit konfeksi yang rata-rata terdiri dari ibu rumah tangga yang merupakan pegawai tetap BUMDes.

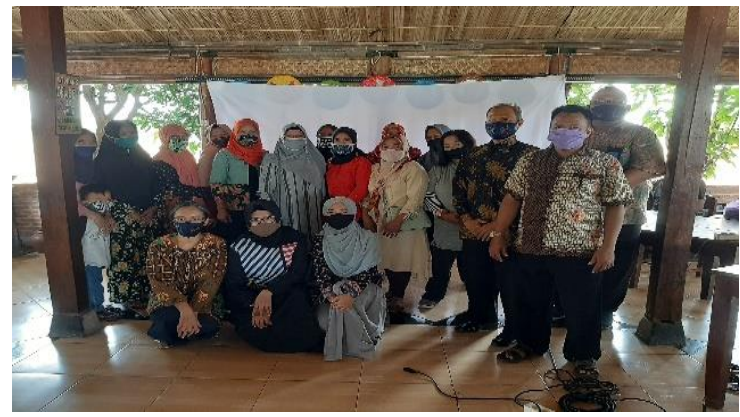

Gambar 4. Peserta pelatihan kewirausahaan dan digital marketing

\section{SIMPULAN}

Hasil pelaksanaan pengabdian di BUMDes Blulukan Gemilang, Colomadu, Karanganyar dapat disimpulkan sebagi berikut:

1. Dari hasil pelaksanaan pengabdian, peserta telah menunjukkan pemahaman mereka mengenai kewirausahaan dan pemasaran

2. Hasil dari pendampingan telah menunjukkan para peserta berhasil mempraktikkan secara mandiri proses pemasaran yang telah diajarkan.

3. Tingkat keberhasilan pencapaian dengan menggunakan indikator pemahaman tentang kewirausahaan dan pemasaran langsung melalui tanya jawab dan tingkat pencapaian 
pendapatan sehingga mampu meningkatkan pendapatan desa.

Berdasarkan hasil monitoring di lapangan, kegiatan pengabdian ke desa seperti pada BUMDes ini seharusnya dilaksanakan secara rutin dan berkala, melihat respon dan tingkat kebutuhan yang baik dari masyarakat dan BUMDes. Rencana kegiatan pengabdian selanjutnya adalah mengadakan pelatihan strategi membangun brand awareness bagi BUMDes dan UMKM.

\section{DAFTAR PUSTAKA}

Adhiyasasti, Menur. (2020). Lima syarat Masker Kain yang Bisa Cegah Tularkan Virus. Available at https://skata.info/article/detail/646/5syarat-masker-kain-yang-bisa-cegahtularkan-virus

Ariyanto. (2019). Digital Marketing BUMDes. available at https://blog.bumdes.id/2020/01/digitalmarketing-bumdes/

Hasmawati, Fifi. (2018). Ekonomi Kerakyatan Berbasis Potensi Lokal. Jurnal Pengembangan Masyarakat, V(5), 54. http://jurnal.uinsu.ac.id/index.php/PEM AS/article/download/4986/2288.

Nugrahaningsih, Putri, dkk. (2020). Ecopreneurship: Perspektif Pembangunan yang Berkelanjutan (Konsep dan Aplikasi di BUMDes Blulukan Gemilang, Desa Blulukan, Karanganayar, Jawa Tengah). Surakarta: UNS Press

Pemerintah RI. (2014). Undang-undang RI Nomor 6 Tahun 2014 tentang desa.

Rahmawati; Murni, S; Suhardjanto, D; Iswanto; Sawitri, D. (2017). Green Entrepreneurship: Konsep dan Aplikasi di desa Eduwisata Hijau Sukunan Yogyakarta. Yogyakarta: Expert.

Ramadana, heru, dan Suwondo. (2013). Keberadaan Badan Usaha Milik Desa (BUMDes) Sebagai Penguatan Ekonomi Desa (Studi di Desa Landungsari, Kecamatan Dau, Kabupaten Malang). Jurnal Administrasi Publik, Vol. 1, No. 6.

Solosae. (2020). Eksistensi Perguruan Tinggi di Tengah Pandemi Covid-19. available at http://solosae.com/2020/09/30/eksistensi -perguruan-tinggi-ditengah-pandemicovid-19/

Sumaryadi. (2005). Perencanaan Pembangunan Daerah Otonom dan Pemberdayaan Masyarakat. Jakarta: CV. Citra Utama.

Sururi, Ahmad, dkk. (2020). Peningkatan Kapasitas Ekonomi Masyarakat Melalui Pemberdayaan Kelompok Usaha Mikro Kecil Dan Menengah Di Kawasan Pantai Utara Desa Domas Kabupaten Serang. Kumawula: Jurnal Pengabdian Kepada Masyarakat, Vol. 3, No. 3.

Susanti, S., Gunawan, W., \& Sukaesih, S. (2019). Pengembangan Pemasaran Bordir dan Kelom Geulis Tasikmalaya Melalui Media Sosial. Jurnal Kumawula: Jurnal Pengabdian Kepada Masyarakat, 2(3), 248-261.

https://doi.org/http://10.24198/kumawula. vli3.25256 